\title{
Influence of heat shock and osmotic stresses on the growth and viability of Saccharomyces cerevisiae SUBSC01
}

\author{
Md. Sakil Munna, Sanjida Humayun and Rashed Noor
}

\begin{abstract}
Background: With a preceding scrutiny of bacterial cellular responses against heat shock and oxidative stresses, current research further investigated such impact on yeast cell. Present study attempted to observe the influence of high temperature $\left(44-46^{\circ} \mathrm{C}\right)$ on the growth and budding pattern of Saccharomyces cerevisiae SUBSC01. Effect of elevated sugar concentrations as another stress stimulant was also observed. Cell growth was measured through the estimation of the optical density at $600 \mathrm{~nm}\left(\mathrm{OD}_{600}\right)$ and by the enumeration of colony forming units on the agar plates up to 450 min.
\end{abstract}

Results: Subsequent transformation in the yeast morphology and the cellular arrangement were noticed. A delayed and lengthy lag phase was observed when yeast strain was grown at 30,37 , and $40^{\circ} \mathrm{C}$, while at $32.5^{\circ} \mathrm{C}$, optimal growth pattern was noticed. Cells were found to lose culturability completely at $46^{\circ} \mathrm{C}$ whereby cells without the cytoplasmic contents were also observed under the light microscope. Thus the critical growth temperature was recorded as $45^{\circ} \mathrm{C}$ which was the highest temperature at which S. cerevisiae SUBSC01 could grow. However, a complete growth retardation was observed at $45^{\circ} \mathrm{C}$ with the high concentrations of dextrose $(0.36 \mathrm{~g} / \mathrm{l})$ and sucrose $(0.18 \mathrm{~g} / \mathrm{l})$. Notably, yeast budding was found at 44 and $45^{\circ} \mathrm{C}$ up to $270 \mathrm{~min}$ of incubation, which was further noticed to be suppressed at $46^{\circ} \mathrm{C}$.

Conclusions: Present study revealed that the optimal and the critical growth temperatures of S. cerevisiae SUBSC01 were 32.5 and $45^{\circ} \mathrm{C}$, respectively; and also projected on the inhibitory concentrations of sugars on yeast growth at that temperature.

Keywords: Heat stress, Osmotic stress, Saccharomyces cerevisiae, Critical growth temperature, Budding yeasts, Viable and culturable cells

\section{Findings}

Stress responses in bacterial cells and to some extent in the yeast cells have been well studied so far [1-18]. Abrupt changes in the environmental and physicochemical stimuli including temperature, $\mathrm{pH}$, sugar/salt concentrations, the redox state, toxic compounds and nutrient exhaustion have been mostly found to elicit a battery of defending response by up-regulating the genes encoding heat shock proteins (HSPs) in bacterial cells [19-27]. Like bacteria, the heat shock response in Saccharomyes

\footnotetext{
*Correspondence: noor.rashed@yahoo.com

Department of Microbiology, Stamford University Bangladesh, 51 Siddeswari Road, Dhaka 1217, Bangladesh
}

cerevisiae, the model experimental yeast species, has been also characterized by the rapid changes in their cellular physiology including the budding manner accompanied with the increased tolerance against elevated salt and sugar concentrations, and against reactive oxygen species (ROS) [1-4, 7, 9-11, 15, 18, 28-30]. In S. cerevisiae, heat-sensitivity is ordinarily prescriptive of defects in protein coding genes which are also essential for maintaining the cell viability $[10,19,24,31-34]$. The coupling consequence of heat stress together with the osmotic shock has been found to influence the cellular degeneration along with the retardation in cell division in yeast cells $[3,7,35]$. 
Our earlier studies revealed the bacterial cellular adaptation in response to the heat shock and against the elevated amount of intracellular reactive oxygen species (ROS) [14, 17, 36-38]. However, the work on stress response in yeast cells is scarce in the local perspective. These led us to broaden the research interest in the yeast cells to assess the optimal and critical growth temperatures and further to investigate intensely the growth changes at the critical temperature accompanied with the simulated stressed condition of an ascending osmotic pressure. Thus, apart from our earlier experiments on bacterial stress responses, current study was designed to observe the stress response in S. cerevisiae SUBSC01 towards heat shock and elevated sugar concentrations. The key observation revealed that while at $45{ }^{\circ} \mathrm{C}$ the yeast strain could grow, conversely growth inhibition was noticed upon supplementation of high concentrations of sugars.

\section{Methods}

On the basis of strain availability, laboratory stock cultures of S. cerevisiae SUBSC01 were used. Sabouraud Dextrose Agar (SDA) (Hi-Media Laboratories Pvt. Ltd., India), Sabouraud dextrose broth (SDB) (Difco Laboratories, Inc. USA) and Sucrose broth (SB) (Sigma-Aldrich Corporation, USA) were used. Pre-cultures were prepared by inoculating $5 \mathrm{ml}$ SDB by a loopful of colony from the freshly prepared yeast culture plates, followed by incubation at $30,32.5,37$ and $40{ }^{\circ} \mathrm{C}$ in static condition up to $72 \mathrm{~h}$. The optical density at $600 \mathrm{~nm}\left(\mathrm{OD}_{600}\right)$ and the capability to form the colony forming units (CFUs) were monitored at the specific time intervals [13]. To determine the critical growth temperature, growth was monitored at 44,45 and at $46{ }^{\circ} \mathrm{C}$. For morphological observations, an aliquot of $5 \mu \mathrm{l}$ from each of the culture suspension was removed at 90 min intervals $[17,39,40]$. For spot dilution tests, $1 \mathrm{ml}$ of the culture suspension at same intervals was removed and serially diluted in $9 \mathrm{ml}$ dextrose broth up to $10^{-4}$ [17]. An aliquot of $5 \mu \mathrm{l}$ from each dilution was then spotted onto SDA plates following incubation at $32.5^{\circ} \mathrm{C}$ for $24 \mathrm{~h}$. To observe the osmotic effect on cell growth, different concentrations of dextrose including $0.04 \mathrm{~g} / \mathrm{l}(1 \mathrm{X}), 0.12 \mathrm{~g} / \mathrm{l}(3 \mathrm{X}), 0.2 \mathrm{~g} / \mathrm{l}(5 \mathrm{X}), 0.28 \mathrm{~g} / \mathrm{l}$ (7X), $0.36 \mathrm{~g} / \mathrm{l}(9 \mathrm{X})$ and sucrose, i.e., $0.02 \mathrm{~g} / \mathrm{l}(1 \mathrm{X}), 0.06 \mathrm{~g} / \mathrm{l}$ (3X), $0.1 \mathrm{~g} / \mathrm{l}(5 \mathrm{X}), 0.14 \mathrm{~g} / \mathrm{l}(7 \mathrm{X})$, and $0.18 \mathrm{~g} / \mathrm{l}(9 \mathrm{X})$ were used. All experiments were conducted in triplicates. Statistical analysis regarding yeast growth was performed by determining the $\mathrm{P}$ value ( 0.3) through $\mathrm{t}$ test. Standard deviations were also measured with the aid of statistical hypothesis testing [17].

\section{Results interpretation and analysis} Optimal growth temperature of Saccharomyces cerevisiae (SUBSC01)

The optimal growth temperature for $S$. cerevisiae SUBSC01 was assessed through the measurement of $\mathrm{OD}_{600}$ and by counting the CFUs up to $450 \mathrm{~min}$. After 90 min of incubation at $32.5{ }^{\circ} \mathrm{C}$ the cell number was found to increase rapidly by approximately 4 logs (Fig. 1), whereas at $30{ }^{\circ} \mathrm{C}$ such tendency was a bit slower (Fig. 1). Interestingly, compared with the growth state at 32.5 and $30^{\circ} \mathrm{C}$, a relatively lengthy lag phase $(\sim 270 \mathrm{~min})$ was observed when cells were grown at 37 and $40{ }^{\circ} \mathrm{C}$, possibly due to the requirement of longer time to cope with temperatures higher than the optimal growth condition (Fig. 1). Besides, under the light microscope, budding
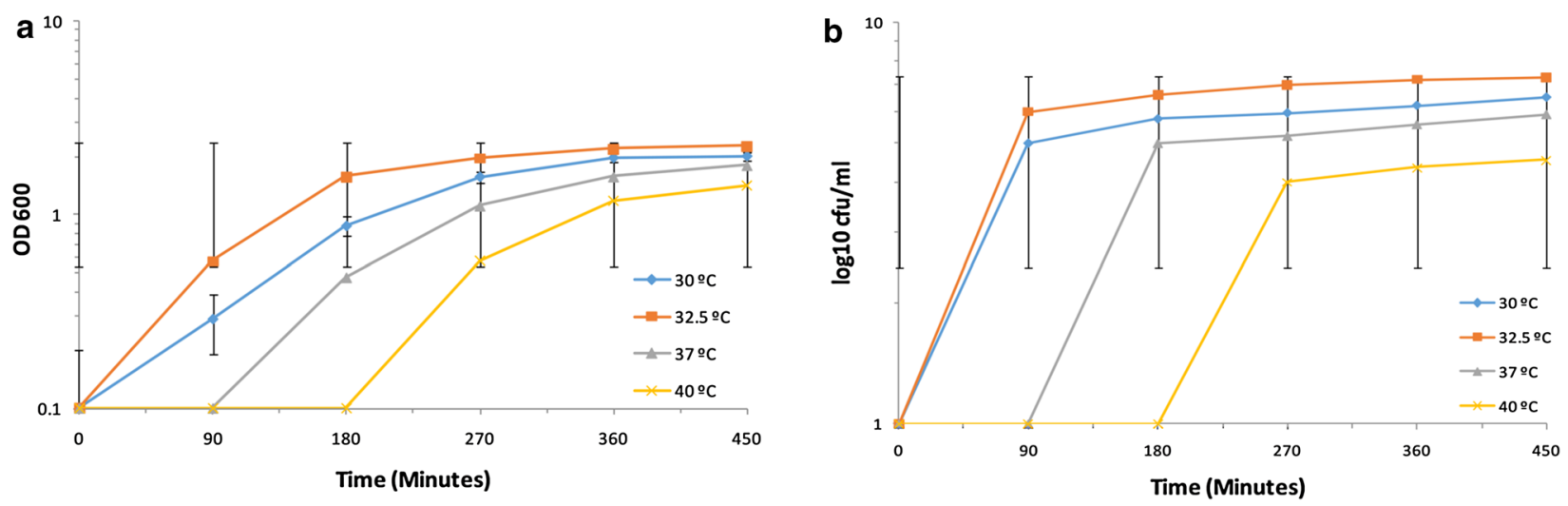

Fig. 1 Assessment of the optimum temperature through the examination of growth of Saccharomyces cerevisiae SUBSC01 in terms of a Optical Density at $600 \mathrm{~nm}\left(\mathrm{OD}_{600}\right)$ and $\mathbf{b}$ the formation of the colony forming units (CFUs). Cells were grown as stated in "Methods", and aliquots were removed at the specific time intervals $(90,180,270,360$ and $450 \mathrm{~min})$ for the assay. A prolonged lag phase ( $270 \mathrm{~min})$ was observed, when cells were grown at $30,37,40^{\circ} \mathrm{C}$. Consequently, the optimum growth temperature of the laboratory stain S. cerevisiae SUBSC01 was estimated to be $32.5^{\circ} \mathrm{C}$ 
yeasts were observed after $90 \mathrm{~min}$ at 30 and $32.5{ }^{\circ} \mathrm{C}$, whereas after 180 min such budding was observed at $37{ }^{\circ} \mathrm{C}$. At $40{ }^{\circ} \mathrm{C}$, the budding events were noticed after 270 min (Fig. 2). The optimal growth temperature for $S$. cerevisiae SUBSC01 was thus noted to be $32.5^{\circ} \mathrm{C}$. However, it is to be mentioned that earlier S. cerevisiae was found to exhibit optimal growth temperature between 25 and $35^{\circ} \mathrm{C}$ as reported by the other groups [41-44].

\section{Critical growth temperature of Saccharomyces cerevisiae (SUBSC01)}

The ability of the yeast strain to grow at $40{ }^{\circ} \mathrm{C}$ led our interest further to examine the maximal growth temperature limit. While a sharp drop was observed in CFU and a relatively lower reduction in the cell turbidity was noticed at 44 and $45{ }^{\circ} \mathrm{C}$ after 180 and $450 \mathrm{~min}$, respectively; notably an inclusive retardation of growth was also observed when cells were grown at $46{ }^{\circ} \mathrm{C}$ (Fig. 3). Interestingly, the budding yeasts were found to become dormant when cells were grown at $45{ }^{\circ} \mathrm{C}$ (Fig. $\left.4 \mathrm{~d}-\mathrm{f}\right)$. In addition, all cells were found without the cytoplasmic contents at $46^{\circ} \mathrm{C}$ (Fig. $4 \mathrm{i}$ ).
An important physiological point is to ponder that unlike Escherichia coli cells, the yeast cells grown at high temperature did not exhibit the characteristics of cell lysis, possibly due to the comparatively rigid cell membrane and cell wall $[13,16]$. However, as has been seen in the current study, the generation of the cells without the cytoplasmic contents due to the deletion of rpoE gene (encoding the RNA polymerase $\sigma^{\mathrm{E}}$ ) in the bacterium Escherichia coli W3110 has also been observed earlier through electron microscopy [16]. In the current study, such an observation of the yeasts cells lacking the cytoplasmic contents under the stressed condition has further drawn the interest on the global impact of heat shock on microorganisms at the cellular level, and led us further to cross-check the expected loss of the cell viability at high temperature by means of the spot dilution tests $[17,38]$. In consistent with the results from the growth assessment, all yeast cells were found to lose the culturability completely at $46^{\circ} \mathrm{C}$ as observed through the spot dilution tests (results not shown). Hence the critical growth temperature of this strain was recorded at $45^{\circ} \mathrm{C}$.

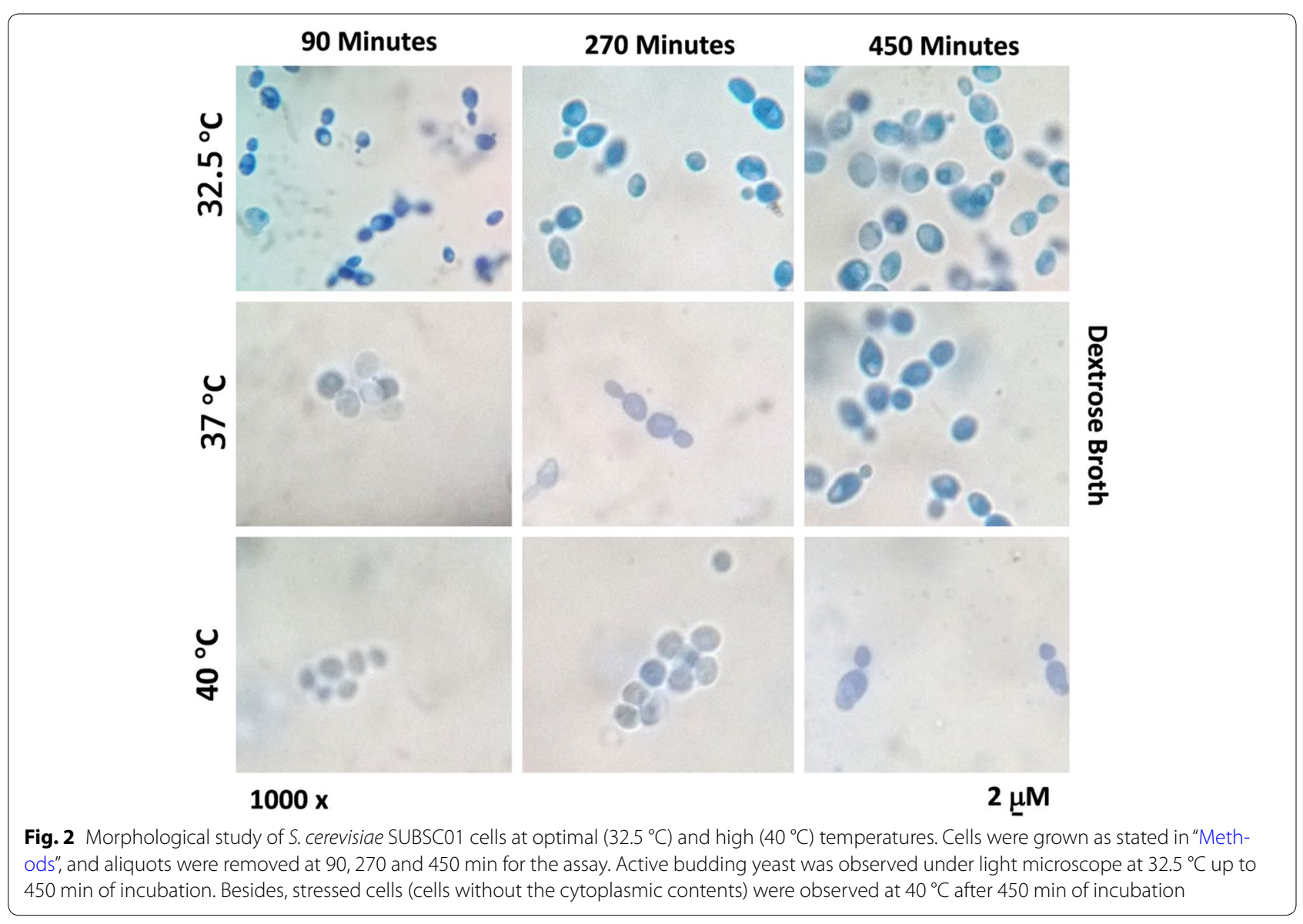





Fig. 3 Effect of high temperatures $\left(44-46^{\circ} \mathrm{C}\right)$ on growth of S. cerevisiae SUBSC01: a impact on cell turbidity and $\mathbf{b}$ influence on the formation of CFUs. Cells were grown as stated in "Methods", and aliquots were removed at the specific time intervals as indicated. A complete decline of both $\mathrm{OD}_{600}$ and CFUs was noticed at $46^{\circ} \mathrm{C}$. The critical temperature of S. cerevisiae SUBSC01 was recorded at $45^{\circ} \mathrm{C}$

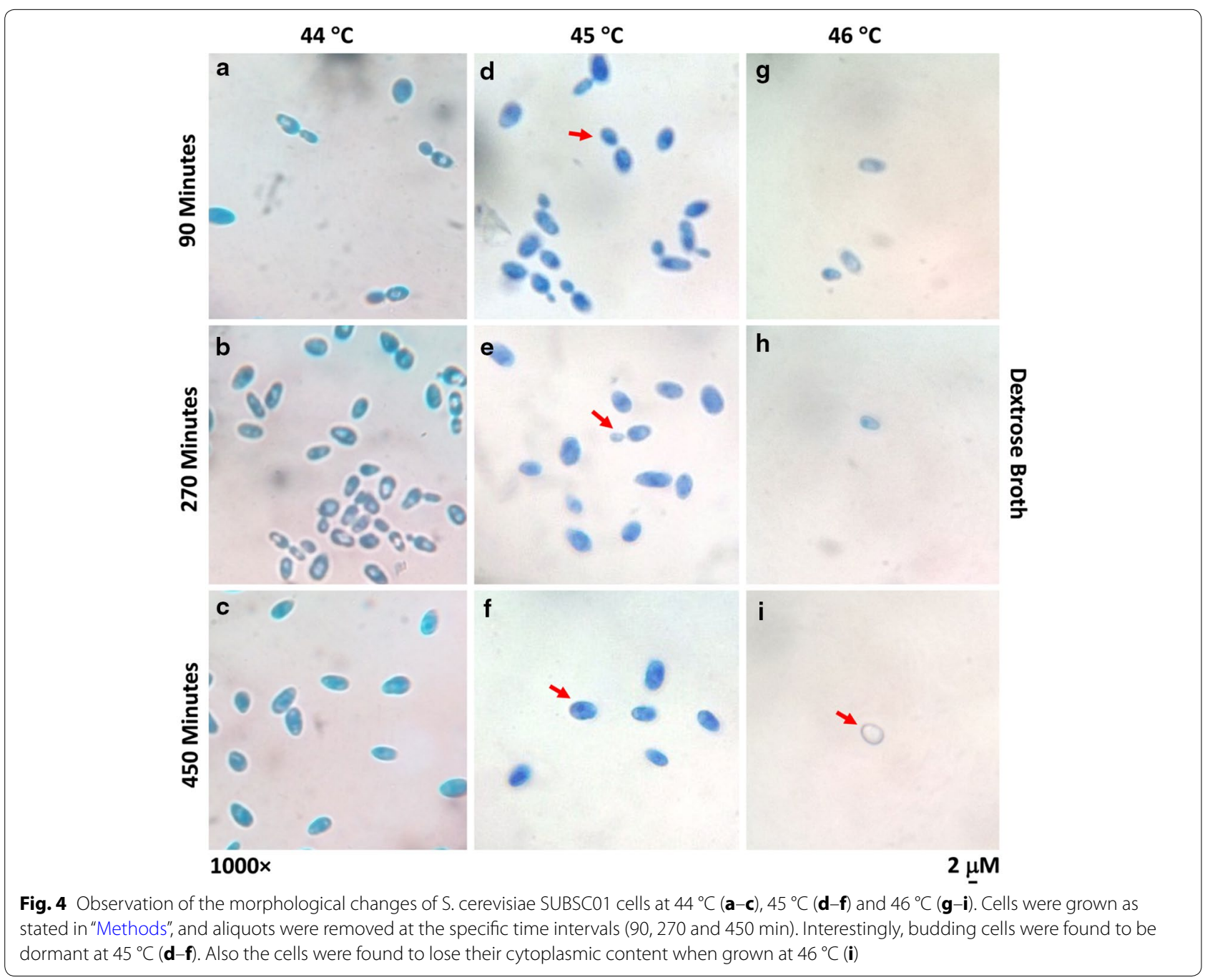




\section{Growth retardation of S. cerevisiae SUBSC01 at critical temperature accompanied with an ascending osmotic shock}

In order to achieve the complete stress response consequences of S. cerevisiae SUBSC01 upon critical temperature, different levels of osmotic pressure were simulated onward. A relatively lengthy lag phase ( 360 min) was observed in both $\mathrm{OD}_{600}$ and CFU in compliance with the extended dextrose concentrations at $32.5^{\circ} \mathrm{C}$ (Fig. 5a, d). Approximately $4 \log \mathrm{CFU} / \mathrm{ml}$ was found to be abolished in $7 \mathrm{X}$ and $9 \mathrm{X}$ dextrose concentrations. Besides, even capable of growing at $45{ }^{\circ} \mathrm{C}$, cells were found to lose their culturability completely at this temperature when the culture medium was supplemented with extremely high (9X) dextrose concentration (Fig. 5c, d). Earlier investigation also showed that yeast cells may exhibit an immediate growth arrest when exposed to an increase in external osmolarity [45]. The prolonged lag phase ( 360 min) in the culturable cells (Fig. 5) led us to examine the probable morphological changes and impairments in the stressed yeast cells afterward. Interestingly the budding cells were found to become quiescent at the optimal temperature with 5X dextrose concentration (Fig. 6g-i), and additionally cells were also found to be thickened (Fig. 6o) at 9X dextrose concentration (Fig. $6 \mathrm{~m}-\mathrm{o}$ ). In cohesion to the current findings, previously, the cell volume of $S$. cerevisiae was also found to expand at $48 \mathrm{~h}$ of incubation periods upon osmotic stress [46]. However, a huge number of cells loosing the cytoplasmic contents were observed at $45{ }^{\circ} \mathrm{C}$ with extreme high $(9 \mathrm{X})$ dextrose concentration (Fig. $6 \mathrm{~m}^{\prime}-\mathrm{o}^{\prime}$ ). Consistently, in the absence of osmotic imbalances no stressed cells (cells without the cytoplasmic contents) were observed at $45^{\circ} \mathrm{C}$.

As stated earlier, $S$. cerevisiae SUBSC01 exhibits approximately $360 \mathrm{~min}$ long lag phase at $32{ }^{\circ} \mathrm{C}$ and complete growth suppression at $45{ }^{\circ} \mathrm{C}$ due to osmotic shock. Elimination of such growth was further supported by the appearance of the stressed cells as seen under the microscope (Fig. $6 \mathrm{~m}^{\prime}-\mathrm{o}^{\prime}$ ). Such results led us to further cross check the stressed physiology of the cells through spot
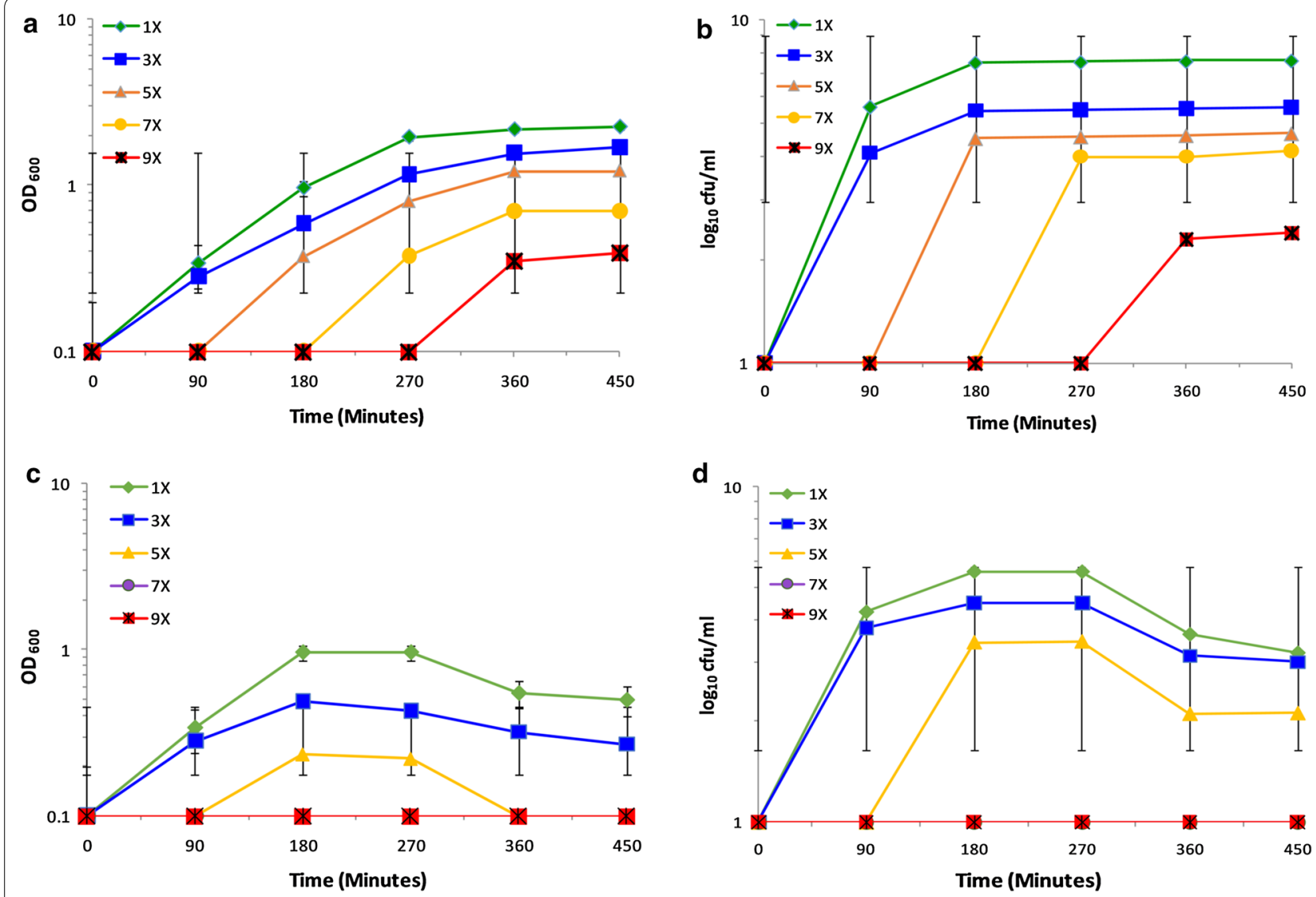

Fig. 5 Growth retardation of S. cerevisiae SUBSC01 at 32.5 and $45^{\circ} \mathrm{C}$ with different dextrose concentrations. Cell culturability was assessed through $\mathrm{OD}_{600}$ and the formation of CFUs at $32.5^{\circ} \mathrm{C}(\mathbf{a}, \mathbf{b})$, and at $45^{\circ} \mathrm{C}(\mathbf{c}, \mathbf{d})$ with different dextrose concentrations, i.e., $0.04 \mathrm{~g} / \mathrm{l}(1 \mathrm{X}), 0.12 \mathrm{~g} / \mathrm{l}(3 \mathrm{X}), 0.2 \mathrm{~g} / \mathrm{l}(5 \mathrm{X})$, $0.28 \mathrm{~g} / \mathrm{l}(7 \mathrm{X}), 0.36 \mathrm{~g} / \mathrm{l}(9 \mathrm{X})$. Cells were grown as stated in "Methods", and aliquots were removed at the specific time intervals of 90, 180, 270, 360 and $450 \mathrm{~min}$. A complete elimination of culturable cells were observed at $45^{\circ} \mathrm{C}$ with $7 X$ and $9 X$ dextrose concentrations (c, d) 




test. At $32.5{ }^{\circ} \mathrm{C}$ in different dextrose concentrations (1X$9 \mathrm{X})$, cells were found culturable through spot dilution tests (results not shown). At $45^{\circ} \mathrm{C}$ under high (9X) dextrose concentration, cells were found to lose their culturability completely. Earlier research found that the activity of $\beta$-fructofuranosidase (SUC2) of S. cerevisiae, which is liable for sucrose degradation; might be repressed by the increased osmotic pressure [28, 32]. This is to be mentioned that when the cells were grown at $32.5{ }^{\circ} \mathrm{C}$ in different sucrose concentrations, all were found to grow after a certain incubation period (results not shown). Nevertheless, the current investigation clearly unraveled the heat stress responsive events in S. cerevisiae SUBSC01, which is comprehensible with the existing knowledge on yeast growth phases and stress physiology.

The revelation of the temperature tolerance of yeast cells as revealed from the current study is consistent with the recent findings $[15,21,47]$. Indeed, deviation in temperature is a general stress encountered by yeast cells [47]. S. cerevisiae is well known to generate the protective transcriptional programs in response to elevated temperatures $[15,21]$. However, those studies mostly showed the temperature tolerance at around $37^{\circ} \mathrm{C}$ while the current study clearly showed that the yeast strain studied 
here could withstand up to $45^{\circ} \mathrm{C}$. Besides, the findings of the critical growth temperature besides the optimal condition, sugar tolerance level, and a bit interestingly the observation of prolonged lag phase at high temperatures may be of significance in the field of yeast physiology. Presented results may provide further general information on the triggering phase of heat shock events in yeast cells. Further studies regarding the expressional analyses of the stress responsive genes would unveil the involvement of the necessary regulons and chaperons required for the stress defense mechanism in the S. cerevisiae SUBSC01.

\section{Authors' contributions}

This work was carried out in collaboration between all authors. MSM managed the literature searches and wrote the first draft, SH performed the experiments, and RN designed the study, analyzed the results and revised the manuscript. All authors read and approved the final manuscript.

\section{Authors' information}

All the authors are from Department of Microbiology, Stamford University Bangladesh. Authors MSM and SH are the thesis students of MS program. The corresponding author RN is working as Associate Professor and Chairman.

\section{Acknowledgements}

Authors thank Stamford University Bangladesh for the logistic supports. However, the authors received no specific funding for this work.

\section{Compliance with ethical guidelines}

\section{Competing interests}

The authors declare that they have no conflict of interest.

Received: 20 November 2014 Accepted: 17 August 2015

Published online: 23 August 2015

\section{References}

1. Brewster JL, de Valoir T, Dwyer ND, Winter E, Gustin MC. An osmosensing signal transduction pathway in yeast. Science. 1993;259:1760-3.

2. Maeda T, Wurgler-Murphy SM, Saito H. A two-component system that regulates an osmosensing MAP kinase cascade in yeast. Nature. 1994;369:242-5.

3. Lewis JG, Learmonth RP, Watson K. Induction of heat, freezing and salt tolerance by heat and salt shock in Saccharomyces cerevisiae. Microbiology. 1995;141:687-94.

4. Turkel S. Effects of various physiological stresses on transcription of the SUC2 gene in the yeast Saccharomyces cerevisiae. Turk J Biol. 2000;24:233-40

5. Nitta T, Nagamitsu H, Murata M, Izu H, Yamada M. Function of the $\sigma^{E}$ regulon in dead-cell lysis in stationary phase Escherichia coli. J Bacteriol. 2000;182:5231-7.

6. Collinet B, Yuzawa H, Chen T, Herrera C, Missiakas D. RseB binding to the periplasmic domain of RseA modulates the RseA: $\sigma^{\mathrm{E}}$ interaction in the cytoplasm and the availability of $\sigma^{E}$ RNA polymerase. J Biol Chem. 2000;275:33898-904.

7. Erasmus DJ, van der Merwe GK, van Vuuren HJJ. Genome-wide expression analyses: metabolic adaptation of Saccharomyces cerevisiae to high sugar stress. FEMS Yeast Res. 2003;3:375-99.

8. Kabir MS, Yamashita D, Noor R, Yamada M. Effect of $\sigma^{S}$ on $\sigma^{E}$-directed cell Lysis in Escherichia coli Early stationary phase. J Mol Microbiol Biotechnol. 2004;8:189-94.

9. Yamamoto A, Mizukami Y, Sakurai H. Identification of a novel class of target genes and a novel type of binding sequence of heat shock transcription factor in Saccharomyces cerevisiae. J Biol Chem. 2005;280:11911-9.

10. Bond U. Stressed out! Effects of environmental stress on mRNA metabolism. FEMS Yeast Res. 2006;6:160-70.

11. Yamamoto N, Maeda Y, Ikeda A, Sakurai H. Regulation of thermotolerance by stress-induced transcription factors in Saccharomyces cerevisiae Eukaryot Cell. 2008;7:783-90.

12. Yamada M, Noor R, Nagamitsu H, Murta M. The higher temperature, the more oxidative stress and lysis in Escherichia coli. The 3rd International Conference on Fermentation Technology for Value Added Agricultural Products: Khon Kaen. 2009.

13. Noor R, Murata M, Nagamitsu H, Klein G, Rain S, Yamada M. Dissection of $\sigma^{\mathrm{E}}$ dependent cell lysis in Escherichia coli: roles of RpoE regulators RseA, RseB and periplasmic folding catalyst Ppid. Genes Cells. 2009;14:885-99.

14. Noor R, Murata M, Yamada M. Oxidative stress as a trigger for growth phase-specific $\sigma^{\mathrm{E}}$ dependent cell lysis in Escherichia coli. J Mol Microbiol Biotechnol. 2009;17:177-87.

15. Morano KA, Grant CM, Moye-Rowley WS. The response to heat shock and oxidative stress in Saccharomyces cerevisiae. Genetics. 2012;190:1157-95.

16. Murata M, Noor R, Nagamitsu H, Tanaka S, Yamada M. Novel pathway directed by $\sigma^{\mathrm{E}}$ to cause cell lysis in Escherichia coli. Genes Cells. 2012;17:234-47.

17. Nur IT, Munna MS, Noor R. Study of exogenous oxidative stress response in Escherichia coli, Pseudomonas spp., Bacillus spp. and Salmonella spp. Turk J Biol. 2014;38:502-9.

18. Tamari Z, Rosin D, Voichek Y, Barkai N. Coordination of gene expression and growth-rate in natural populations of budding yeast. PLOS ONE. 2014;9:e88801.

19. Sanchez Y, Lindquist SL. HSP104 required for induced thermotolerance. Science. 1990;248:1112-5.

20. Virgiliol CD, Pipes P, Boll T, Wiemkenl A. Acquisition of thermotolerance in Saccharomyces cerevisiae without heat shock protein hsp104 and in the absence of protein synthesis. FEBS Lett. 1991;288:86-90.

21. Verghese J, Abrams J, Wang Y, Morano KA. Biology of the heat shock response and protein chaperones: budding yeast (Saccharomyces cerevisiae) as a model system. Microbiol Mol Biol Rev. 2012;76:115-58.

22. Raina S, Missiakas D, Georgopoulos C. The rpoE gene encoding the $\sigma^{\mathrm{E}}$ (sigma 24) heat-shock sigma factor of Escherichia coli. EMBO J. 1995;14:1043-55.

23. Missiakas D, Mayer MP, Lemaire M, Georgopoulos C, Rania S. Modulation of the Escherichia coli $\sigma^{\mathrm{E}}$ (RpoE) heat-shock transcription factor activity by the RseA, RseB and RseC proteins. Mol Microbiol. 1997:24:355-71.

24. Glover JR, Lindquist S. Hsp104, Hsp70, and Hsp40: a novel chaperone system that rescues previously aggregated proteins. Cell. 1998;94:73-82

25. Ishihama A. Modulation of the nucleoid, the transcription apparatus, and the translation machinery in bacteria for stationary phase survival. Genes Cells. 1999;4:135-43.

26. Ades SE. Control of the alternative sigma factor $\sigma^{\mathrm{E}}$ in Escherichia coli. Curr Opin Microbiol. 2004;7:157-62

27. Morimoto RI. The heat shock response: systems biology of proteotoxic stress in aging and disease. Cold Spring Harb Symp Quant Biol. 2012;76:91-9.

28. Blomberg A. The osmotic hypersensitivity of the yeast Saccharomyces cerevisiae is strain and growth media dependent: quantitative aspects of the phenomenon. Yeast. 1997:13:529-39.

29. Yamamoto A, Ueda J, Yamamoto N, Hashikawa N, Sakurai H. Role of heat shock transcription factor in Saccharomyces cerevisiae oxidative stress response. Eukaryot Cell. 2007;6:1373-9.

30. Moraitis C, Curran BPG. Reactive oxygen species may influence the heat shock response and stress tolerance in the yeast Saccharomyces cerevisiae. Yeast. 2004;21:313-23.

31. Parsell DA, Kowal AS, Singer MA, Lindquist S. Protein disaggregation mediated by heat-shock protein Hsp 104. Nature. 1994;372:475-8.

32. Hampsey M. A review of phenotypes in Saccharomyces cerevisiae. Yeast. 1997;13:1099-133.

33. Liu CL, Ge P, Zhang F, Hu BR. Co-translational protein aggregation after transient cerebral ischemia. Neuroscience. 2005;134:1273-84.

34. Gibney PA, Lu C, Caudya AA, Hess DC, Botstein D. Yeast metabolic and signaling genes are required for heat-shock survival and have little overlap with the heat-induced genes. PNAS. 2013; E4393-E4402. 
35. Rowley A, Johnston GC, Butler B, Werner-Washburne M, Singer RA. Heat shock-mediated cell cycle blockage and G1 cyclin expression in the yeast Saccharomyces cerevisiae. Mol Cell Biol. 1993;13:1034-41.

36. Noor R, Islam Z, Munshi SK, Rahman F. Influence of temperature on Escherichia coli growth in different culture media. J Pure Appl Microbiol. 2013;7:899-904

37. Munna MS, Nur IT, Rahman T, Noor R. Influence of exogenous oxidative stress on Escherichia coli cell growth, viability and morphology. Am J Biosci. 2013;1:59-62.

38. Munna MS, Tamanna S, Afrin MR, Sharif GA, Mazumder C, Kana KS, Urmi NJ, Uddin MA, Rahman T, Noor R. Influence of aeration speed on bacterial colony forming unit (CFU) formation capacity. Am J Microbiol Res. 2014;2:47-51.

39. Cappuccino JG, Shermen N. Microbiology; Laboratory manuals. San Francisco: Benjamin/Cummings Publishing Company Incorporated; 1996.

40. McKenzie CGJ, Koser U, Lewis LE, Bain JM, Mora-Montes HM, Barker RN, Gow NAR, Erwig LP. Contribution of Candida albicans cell wall components to recognition by and escape from murine macrophages. Infect Immun. 2010;78:1650-8.

41. Walsh RM, Martin PA. Growth of Saccharomyces cerevisiae and S Saccharomyces uvarum in a temperature gradient incubator. J Inst Brew. 1977:83:169-72
42. Tai LS, Daran-Lapujade P, Walsh MC, Pron JT, Daran JM. Acclimation of Saccharomyces cerevisiae to low temperature: a chemostat-based transcriptome analysis. Mol Biol Cell. 2007;18:5100-12.

43. Salvado Z, Arroyo-Lopez FN, Guillamon JM, Salazar G, Querol A, Barrio E. Temperature adaptation markedly determines the growth and evolution within the genus Saccharomyces. Appl Environ Microbiol. 2011;77:2292-302.

44. Lopez-Malo M, Querol A, Guillamon JM. Metabolomic comparison of Saccharomyces cerevisiae and the cryotolerant species S. bayanus var. uvarum and S. kudriavzevii during wine fermentation at low temperature. PLoS ONE. 2013;8:e60135.

45. Wuytswinkel OV, Reiser V, Siderius M, Kelders MC, Ammerer G, Ruis H, Mager WH. Response of Saccharomyces cerevisiae to severe osmotic stress: evidence for a novel activation mechanism of the HOG MAP kinase pathway. Mol Microbiol. 2000;37:382-97.

46. Pratt PL, Bryce JH, Stewart GG. The effects of osmotic pressure and ethanol on yeast viability and morphology. J Inst Brew. 2003;109:218-28.

47. Kanshin E, Kubiniok P, Thattikota Y, D'Amours D, Thibault P. Phosphoproteome dynamics of Saccharomyces cerevisiae under heat shock and cold stress. Mol Syst Biol. 2015;11(6):813.

\section{Submit your next manuscript to BioMed Central and take full advantage of:}

- Convenient online submission

- Thorough peer review

- No space constraints or color figure charges

- Immediate publication on acceptance

- Inclusion in PubMed, CAS, Scopus and Google Scholar

- Research which is freely available for redistribution

Submit your manuscript at

www.biomedcentral.com/submit
C Biomed Central 